\title{
GRAHAM IVE AND THE METHODOLOGY OF CONSTRUCTION ECONOMICS
}

\author{
Gerard de Valence and Goran Runeson \\ School of the Built Environment, Faculty of Design Architecture and Building, \\ University of Technology Sydney \\ gerard.devalence@uts.edu.au and Karl.Runeson@uts.edu.au
}

\begin{abstract}
Graham Ive's central contribution to our methodological debate was his insistence on the firm as the analytical unit. Ive argues we should reject theories if the aspect of construction we are examining does not satisfy the assumptions of a particular theoretical model. We see this in his rejection of neoclassical economic theories in the two topics discussed in this paper: the adoption of innovations in construction; and microeconomic analysis as it relates to price determination in the market for construction. The former requires studying not just participants in the building process, but also participants in the innovation process, and the latter uses post-Keynesian pricing theory where prices are set according to mark-up procedures and vary with costs, but not directly with demand. This is in contrast to the general equilibrium, perfectly competitive price setting of neoclassical economics. Ive and his collaborators show a way towards better research in their emphasis on theory and the insistence that for building economics the analytical units are the industry and the firm, not the project. Ive's concern is that the processes involved in organising the production of buildings should be seen as a distinctive and defining element of our analysis of the industry.
\end{abstract}

Keywords: Methodology, construction economics, construction industry, innovation, price determination. 


\section{Introduction}

This is a discussion of the methodology of construction economics and how the selection of theories imposes discipline on research. Across the research published by Graham Ive since the 1980s methodology has been a recurrent theme, and he has argued an important methodological problem in construction economics research is due to the acceptance of neo-classical microeconomics. That argument is the subject of this paper.

Methodology is not an issue that features in the construction literature. There was a short debate on the merits of qualitative research following the publication of a paper by Seymour and Rooke (1995) and a subsequent paper by Seymour, Crook and Rooke (1997). Seymour and his colleagues maintained a positivist approach to construction management research is not appropriate because they see construction management as a sub-branch of management studies, or the study of human activities:

The difficulty of doing management research is compounded because the discipline intends to produce advice for practitioners. This requires theorists to make value judgements, a process logically incompatible with the attempt to achieve a depersonalized objectivity. (1997: 119).

Their paper attracted a number critical comments by Runeson (1997), from Chau et al. (1998) and Harriss (1998), followed by a rejoinder to Runeson by Seymour et al. (1998), after which the debate ran out of steam. This debate is relevant here because Runeson completely rejected the approach advocated by Seymour et al.:

positivism currently offers the best way to reduce subjectivity and to discipline undisciplined researchers and the results, in terms of advancement of science, are nothing short of spectacular. Why reject it for something less useful? (1997: 302). 
This touches on the core issue in Graham Ive's approach to methodology. He argues we should reject theories whenever for some reason we feel that the aspect of construction we are examining does not completely satisfy all the assumptions of a particular theoretical model. We can see this in his rejection of neoclassical economic theories in the two important topics discussed in this paper:

- the adoption of innovations in construction as an economic or a technical issue; and

- microeconomic analysis as it relates to price determination in the market for construction management services.

In each case there are widely accepted and tested theories ${ }^{1}$ that could be used but Ive and Groak (1986) in the first case and Gruneberg and Ive (2000) in the second reject them in favour of an alternative theoretical framework. In considering Ive's approach to these issues we can see the strengths and weaknesses of both sides of the positivist and alternative approaches.

\section{Its the Firm not the Project}

Graham Ive's central contribution to our methodological debate was his insistence on the firm as the analytical unit in economic theory. This can be seen in Ive and Groak (1986), and in Ive (1990) the link between firm strategy and industry structure is explored. It was particularly the case in his books with Gruneberg (Ive and Gruneberg 2000, Gruneberg and Ive 2000) although these, like Hildebrandt (1974, Hillebrandt and Cannon 1990) and Cassimatis (1969) previously, failed to sway the major part of the discipline to follow suit.

\footnotetext{
${ }^{1}$ Any introductory text in Economics will cover price determination and innovation.
} 
This means that currently, in the greater part of construction economics research, we have a phantom industry, made up of individual and totally independent projects and firms do not exist. There are exceptions to this, typically when the focus is on longer-term relationships (Smyth and Pryke 2008) or on corporate strategy in some form (Runeson and de Valence 2008). The fact is that firms exist through time as they undertake projects in sequence, while an individual project is a passing phenomena undertaken by a temporary team. Bröchner (2011) argued for construction economics to become more engaged with theories of industry economics and to recognise that it is not projects but individuals and firms that maximise utility and profits, and respond to incentives.

In part, this failure to convince the discipline about the importance and existence of firms was probably self-inflicted. Rather than demonstrating how the mainstream neo-classical theories could be used, even in situations where the assumptions did not seem to fit the reality of the construction industry, Ive and his collaborators introduced alternative theories whenever they encountered differences between the theoretical model and reality. From the positivist viewpoint the selection of theories depends on the question we ask, not on how closely the reality appears to match the assumptions of the theories, and there have to be strong reasons to reject a theory that in other contexts provides answers to our questions. However:

Our approach, by contrast, is to start by making a model of the actual processes by which economic actors arrive at their decision - in terms which we hope will be recognised by practitioners as capturing certain (inevitably, not all) interesting or significant parts of that process. ....

The substantive content of our theory is to an extent eclectic, formed by taking and melding together, magpie-like, whatever catches our interest from a diverse range of sources. (Ive and Gruneberg 2000: xxiii) 
The theories Ive and his collaborators have sought out frequently answer interesting questions, but the variety can make their works on microeconomics read more like an inventory of theories from sociology, psychology and institutional economics than an integrated framework for research into the economics of building. This of course, Ive would say, reflects the characteristics and nature of the industry we are studying.

Acceptance of multiple research programmes in the same field was one of the main ideas proposed by Lakatos (1977), with the merit of each one judged on how well it points to future (science) research and how well it explains or predicts real phenomena. Chau et al. (1998) also believed that a variety of methodological approaches can be used, in their case for construction research. They argue for "methodological pluralism and paradigm diversity" (1998: 103) and that research should be judged on the quality of execution and the characteristics of the knowledge gained.

In practice Ive's argument is strongly against neo-classical economics, for example in chapter 2 of Ive and Gruneberg (2000) on the labour market, where capital-labour substitution is denied in favour of deskilling labour through specialisation to pay lower wages by contractors. Alternative approaches to neoclassical orthodoxy are the hallmark of Ive's methodological investigations.

Interestingly, the challenge to neoclassical thinking and encouragement of a pluralistic approach has been endorsed by many economists since the financial crisis of 2007-09 and the ongoing consequences. In particular, the Curriculum Open-access Resources in Economics (CORE) ebook that The Institute for New Economic Thinking released in late 2014 was created collaboratively, using input from academics, policy makers, professional economists and students in several countries. 
Their internet-based Introduction to Economics course is described as "teaching economics as if the last three decades had happened". ${ }^{2}$

Also in this context the work of Lawson $(1997,2003)$ should be mentioned. He argues there has been something wrong with academic economics for some time, mainly because of the use of concepts widely accepted as fictitious, such as rational expectations, representative agents, two commodity worlds and human super-calculators. He believes the problem is the reliance on formal methods of mathematical deductive modelling; and that there is a basic mismatch between the mathematical methods employed and the nature of the social, including economic, phenomena that economists seek to illuminate. These methods have also notably failed as predictors of events.

\section{Ive on Technology}

The paper by Ive and Groak (1986) on technological change included a wide ranging discussion on innovation, barriers to development, and the relationships between economic, organisational and technical change. There was also a potted history of the Bartlett Production of the Built Environment series in the early 1980s and of several decades worth of UK inquiries and reports into the industry. They declared their intention as:

a preliminary attempt to indicate a unified theory of economic and technological change in the building industry. It is limited to a consideration of that part of industrial change which might be termed "deliberate", that is, cases where analysis and identification of situations and trends has helped form conscious strategies (1986: 115).

\footnotetext{
${ }^{2}$ See The Institute for New Economic Thinking site at http://ineteconomics.org/about and http://core-econ.org/ for details.
} 
Innovation is an area where we have a perfectly good economic theory but where home-made theories are flourishing. There is some good research here, based on the idea that innovation is an investment that requires not only the technology embedded in the innovation but also the return on investment before it is undertaken - although some of this research is spoiled by the use of the project as the analytical unit rather than the firm. However the majority of research appears to be based on two assumptions: that if the technology is there it should be employed and anyone not doing so is either too stupid or old-fashioned to understand their own good. A good example of this approach is the publication in 2005 of two volumes by the Australian Cooperative Research Centre for Construction Innovation (Brown, Hampson and Brandon 2005) where in 63 chapters on innovation, there is no mention of costs, rate of return or profit, or any other economic issue.

In economic theory, innovation is a question of profit. To be implemented, an innovation needs to generate additional profit. This has two implications. Firstly, the innovation must reduce costs or improve the attractiveness (utility) of the product more than its costs. Secondly, the innovator needs sufficient market power to be able to expropriate the extra profit ${ }^{3}$. One of the characteristics of the construction industry is the transfer of intellectual property from tenderers to clients if the procurement process includes submission of design ideas, which may not be paid for. Further, as de Valence (2010: 57) concludes, "the traditional tendering process used by construction industry clients has them typically select on price and not pay for innovation in particular or intellectual property in general. This does not allow tenderers to appropriate the benefits of knowledge, thus removing the main incentive to innovation."

As in most other industries there are two kinds of innovations, product and process innovations (see Smyth 2010 for examples of both in construction). Product innovations are innovations that improve the product itself. With the separation of design from production in most of the industry, very few

\footnotetext{
${ }^{3}$ This is illustrated by the use of patents which serve to create a monopoly for the innovator to allow him/her to recoup the costs of developing the innovation.
} 
firms have control over the design and therefore lack the market power to expropriate the return from any product innovation. With the exception of some of the largest residential developers and a few global firms, builders have no market power and are therefore unlikely to benefit from any product innovation. They get the description of the product from the architect and just implement the design.

Process innovations are somewhat different. They are innovations that reduce the cost of production. If the costs of introducing them are reasonable, they may increase profit. However, there is a penalty on being the first to introduce a process innovation. While the technology behind the innovation may be common property across the industry, there is normally a cost associated with transforming it from an idea to an innovation. However, the way the industry operates, once someone has developed the principles behind the innovation, it will quickly spread across the industry and the only difference between the innovator and the follower is that the second and subsequent innovators will get most or all of the benefits of the innovation without paying anything for the development. This is referred to as the advantages of being second - all the benefits but none of the costs. There are two reasons this is the case: firstly, on-site work is quite easy for competitors to observe, and thus copy; and secondly, the subcontractors and workers on a project will take their knowledge of the innovation with them when they move on to their next project, which will often be run by a different head contractor. This is why firms are sometimes hesitant in developing new technologies. Note also that everything in this explanation requires that the economic agent is the firm, not the project.

As we have seen, economic theory can explain and predict which of potential innovations will be adopted and why. More importantly, it can be used to demonstrate that decision makers in the industry are not necessarily old-fashioned if they don't adopt new technologies. In the same way that economic theory removes the incompetence necessary for the errors in costing that are the 
central part of tendering theory, it removes old-fashionedness as an explanation why new technologies may not be adopted. In other words, economic theory changes construction managers from being incompetent and old-fashioned into being the same as managers in other industries, people using competence and rational criteria for their decision making. Economic theory gives us modern skilled construction management.

In contrast, Ive and Groak suggest that the distinction between product innovation and process innovation makes sense in some manufacturing industries but is less satisfactory for the building industry (1986: 116). This is due to a synthesis of process and product (whole buildings) not found in manufacturing where the organisation of production is in factories turning out standardised units. Their argument is that barriers to technological changes are found in the form of organisation of the building process, and the distinctive characteristics of the process such as fragmentation. From their analysis they identified three distinct approaches to technological change in the building industry: an economic determinism; a technological determinism; and the development of the division of labour (1986: 125).

They suggest an economic determinism underlay the UK studies of the 1960s and 1970s, where the building industry is seen as a responsive industry that has to wait on effective demand (actual contracts) before it knows its workload, organisation or product in terms of timing, location, or technology. Therefore technical change will not be instigated by contractors because of the risk involved, unless this risk can be reduced by stabilisation of demand (taken to be the role of the public sector as client). Ive and Groak were not prepared to:

reduce the influence of economic conditions on the process of innovation to the single variable of "rate of increase in effective demand", and wish to insist upon the relevance of variables which measure industrial structure (concentration ratios, barriers to entry, etc.), pricing behaviour, financial structure (gearing and debt ratios, rate of turnover of capital 
employed), cost structure, market conditions, and profitability (at the very least -this list is far from exhaustive) (1986: 127).

They were also not willing to reduce questions of technology to the output of R\&D activity, nor to treat technology as something external and exogenous to the production process of building itself. This emphasis on the importance of the building process reoccurs throughout Ive's work. They also believed their study of changes in the division of labour in construction offered possibilities for a synthesis of discussion of economic and technological factors, while also emphasising questions of social relationships (Pryke 2004).

Ive and Groak's paper focused on advantages and constraints to innovation in construction, and despite being over two decades old, this work captures many of the key features of the discussion raised by more recent efforts such as Reichstein et al. (2005), Fairclough (2002), or Slaughter (1998). Their interesting and challenging paper concluded:

We have identified some aspects of analysis of industrial change whose limitations and lack of a theory relevant to building activity lead us to argue for a unified economic/technical framework founded in the building process. Such a programme would involve studying not just participants in the building process, but also participants in the "innovation process" (1986: 128)

\section{Price Setting in Construction}

It is easy to see that the conventional model of price determination - where marginal cost is equated to marginal revenue - doesn't seem to fit building and construction very well. All projects are different and located in different places. The buildings have not yet been built, so no-one actually 
knows what the costs will be. Each contract may account for up to a quarter of the firm's turn-over, making it difficult to determine marginal costs. Transaction costs can be high (Ive and Chang 2007) and principal-agent issues are common (Chang and Ive 2007). Finally, the actual process of a single sealed tender is not really one we see in the supermarkets where we assume economic theories are demonstrated. In fact it is not too far off to say that there is no evident market.

The economic theory of price determination is simple: the market will clear at the quantity and price where marginal revenue and marginal costs are equal. However, there are different kinds of markets depending on the number of sellers and buyers that compete against each other. We have perfect competition, monopolistic competition, oligopoly, duopoly, monopoly, monopsony, bilateral monopolies etc. and the price outcome in each type of market structure is different. However, they can all be explained by the same theory simply by changing the auxiliary statements to create different models. For perfect competition we have many buyers and many sellers producing identical products. For monopolistic competition we have many buyers and many sellers producing differentiated products, etc. By keeping the theory but changing the auxiliary statements, we can accommodate all of these different markets within the economic theory of price determination.

Some of the new auxiliary statements that are required for economic theory to apply for construction economics are fairly standard. Something like 90 per cent of all intermediate production are sold through tenders - in most cases before actually produced, so these aspects are no problem. Arrow (1959), an eminent economist, referred to this process of tendering as the mechanism of price determination when markets change that is implicit in the economic models. Most producers also have a limited number of buyers. For most services, and construction management is a service, there are differences in quality and quantity, but economic theory can accommodate this. The costs of most construction management services are determined by aggregating a number of different items just like the cost of a meal in a restaurant. 
Conceptually, there is no question that economic theory cannot apply although in practice it may be necessary to add some auxiliary statement to account for what is presumably a discontinuous marginal cost functions, caused by the size of typical projects in relation to the firm. This should be no fundamental problem as we already use a discontinuous marginal revenue curve in the model of the kinked demand curve (Runeson, 2000). The point is that we do not have to reject a theory just because our auxiliary statements do not match reality - we can change our models by changing our auxiliary statements until they do.

This is not the view of the post-Keynesians. The term post-Keynesian is used to identify economists with an intellectual debt to Keynes who are dissatisfied with orthodox neoclassical theory, and who stress the importance of uncertainty and finance in their work. The neoclassical view of the economy is one where perfectly informed, rational producers and consumers are linked by markets where prices adjust (up and down) smoothly and without friction to bring supply and demand into equilibrium. Contrast this view to an industry where consumers (i.e. clients) are forecasting demand for their stock of buildings and structures years in the future, with the uncertainty that entails, and producers (contractors, subcontractors and suppliers) cannot accurately anticipate demand from one year to the next. There is no equilibrium level of output in a project based industry, because output is lumpy, there is only the value of work done in any period, which will be different in the next period.

Post-Keynesians are interested in understanding the process through which investment, savings, and financing decisions are determined in an economy where the future is uncertain, production takes time, and the capital stock is not malleable. All factors that are assumed away in the mathematical models of neoclassical economists. Further, the capital stock in construction is also very difficult to 
define (Briscoe 2006, de Valence 2001) and measure (Lowe 1990). This is a wider set of changes to pricing theory than a few modifications to auxiliary statements will allow.

Clearly, this sort of view of economic decisions will appeal to Ive, with his interest in the processes involved in decision-making under uncertainty and his ease with indeterminate rather than equilibrium outcomes. His approach is aligned with post-Keynesian economics as both are based on inductive theories that explore actual determinants and causal processes involved in pricing decisions. Also clearly, this sort of approach is not similar or compatible in any way to the fully informed optimising accounts of equilibrium pricing discussed above. Harcourt (2006) is a good introduction to the development of post-Keynesian theory.

Post-Keynesian pricing has prices set according to mark-up procedures and varying with costs, but not directly with demand, in contrast to the general equilibrium, perfectly competitive price setting of neoclassical economics. The fundamental difference between neoclassical and post-Keynesian pricing theory is in this emphasis on mark-up procedures and the asymmetrical effects of costs and demand upon prices, and it is in these two areas that Gruneberg and Ive (2000, chapters 9 and 10) stake out their theory, in their eclectic way.

Gruneberg and Ive echo the theories of important post-Keynesians such as Kalecki (1954) and Andrews (1964), who are cited, but also Hall and Hitch (1939) and Means (1972) among others who are not. These theories are based on observations about the operations of the firm and attempt to represent the real world through their assumptions and claims. For example, Kalecki's (1954) theory emphasises how average costs at the firm level are marked up, but are constrained by factors such as union power, sales and promotion activities, the degree of concentration in the market, the level of overheads to be covered and the prices of competing products. 
Including a range of firm-specific and industry-specific factors in pricing decisions, and the subsequent profit margin, is also the aim of Gruneberg and Ive. The link they emphasise is between construction firms' pricing and investment strategies, based on their view that contractors need to raise their level of investment to meet the increase in costs of increased output. Gruneberg and Ive use a model based on Eichner (1973) and Wood (1975):

This model will bring together the concepts of pricing, output, finance, profit margins and gross operating profits, but it is the inclusion of growth which introduces a dynamic element, allowing for change and uncertainty (2000: 201).

The representative firm for post-Keynesians is Eichner's 'Megacorp' (1976), a large multiproduct, multi-industry firm that sets prices in oligopolistic markets, which is in turn based on Eichner's (1973) model of pricing in a microeconomic model of oligopolistic behaviour. In this model the price-leading Megacorp maximises growth subject to institutional constraints such as competition and entry to the market. This model is applied by Gruneberg and Ive to the large construction firm to show that, following Ive's (1994) conclusion that large contractors meet their need for operating capital by cash-flow balancing or by profit-smoothing, the major contractors adopt strategies consistent with low levels of investment, unlike large firms in other industries such as manufacturing.

Another important distinction introduced by Gruneberg and Ive is the difference in pricing behaviour between large construction firms and small firms, which they describe as near-firms or micro-firms. The large firms are oligopolistic, an important but often overlooked point, but small firms operate under conditions that closely resemble those of perfect competition and are "constrained by a chronic shortage of operating financial capital" (2000: 225).

Neoclassical theory bases prices on the values of products determined by scarcity or utility, although prices may also reflect marginal productivity and marginal costs (assuming perfect competition). 
However, post-Keynesian theory bases prices on the particular situation of a firm. Products have no natural or normal prices, they are priced differently by different firms, and quite possibly differently by the same firm at different times (for example, across the building cycle). Gruneberg and Ive argue the imperative for large main contractors is to maintain sales volume to avoid injections of working capital. Prices thus are firm rather than product specific, and each firm will have its own amount of capital based on the relationship between its level of output and changes in demand, so Gruneberg and Ive argue:

The price and output decision within a production period is essentially a selection of the gross mark-up, in the light of the expected impact of price on output volume and on net operating profit. (2000: 216).

The explanation advanced by Gruneberg and Ive is that fixed costs for a production period are known, but firms pricing decisions are constrained by the price elasticity of demand. Post-Keynesians generally would accept fixed costs are more important in the real world than in economic theory, because businesses have difficulty in conceptualising marginal and average cost differences. This undermines the assumptions of rising marginal costs and diminishing factor productivities found in neoclassical theory, and emphasises Gruneberg and Ive's view that neoclassical price theory will not satisfactorily explain the diversity of pricing behaviour seen in the building and construction industry.

\section{Conclusion}

An eclectic approach to theory allows searching for and choosing the theory thought to be most appropriate. For a complex and multi-faceted industry such as building and construction this is an attractive approach. Although the outcome can lack consistency, it avoids the need to fit the facts to 
a theoretical framework that may not suit. For Graham Ive that unsuitable theoretical framework is neoclassical economics.

The neoclassical explanation of technological change in the building industry was rejected by Ive and Groak in favour of one founded on the roles of participants in the building process and their contribution to the 'innovation process' found in the industry. This was not some random process of trial and error but a series of strategic decisions made by both firms and participants, with a strong social dimension.

Joan Robinson, a founder of post-Keynesianism, said a complete theory to take the place of neoclassical theory "would be only just another box of tricks" (1979: 119). This is perhaps why Ive has argued for the right to pick and choose "magpie-like" from a wide range of theories. Like Ive one can adopt a horses for courses approach to issues as they come up in order to find the best explanation for observed facts (Hamouda and Harcourt 1988). This is a perfectly respectable methodological position to take, on the proviso that suitable and rigorous criteria are applied to test the quality of the results.

What distinguishes post-Keynesian theory from neoclassical economics is the emphasis on the importance of the firm, the foundation of Ive's methodology. The post-Keynesian theory of mark-up pricing sits well within the processes at work inside firms, and is the basis of Ive's approach to pricing, which could be seen as the microfoundations of a theory of construction economics. Also, in following Eichner's approach to the financing requirement of firms, Gruneberg and Ive identified an important relationship between the building cycle/market, a contractor's level of output and the need for operating capital. 
The writings of Ive and his collaborators show a way towards better research in their emphasis on theory and the insistence that for building economics the analytical units are the industry and the firm, not the project. This is reflected in Ive's concern that the processes involved in building, or more precisely organising the production of buildings, should be seen as a distinctive and defining element of our analysis of the industry. Together with this, the willingness to manipulate the auxiliary statements of theories so that the models we use matches the essential aspects of the industry we are examining gives us the best assurance of finding a robust methodology in our discipline. This is an approach also favoured by Chau et al. (1998) in their advocacy of methodological pluralism in construction research.

A wide range of economists now argue for rejection of neoclassical economic methodology, and it may be that construction economists are part of a wider community of economists outside the orthodox mainstream. Graham Ive certainly is a member of that community. This review of his research on innovation and price determination in the building industry shows that many of his findings are important, and are buttressed by a wider literature than he often cites, and will continue to be widely used by researchers in the field.

\section{References}

Andrews, P.W.S. 1964. On Competition in Economic Theory. London: Macmillan.

Arrow, K.J. 1959. Towards a theory of price adjustments, in Arrow, K.J. (ed.) The Allocation of Economic Resources, Stanford: Stanford University Press. 
Briscoe, G. 2006. How reliable are construction statistics? Building Research \& Information, 34: 3, 220-29.

Bröchner, J. 2011. Developing construction economics as industry economics, in de Valence, G. (ed.) Modern Construction Economics: Theory and application, Oxford: Spon Press, 14-28.

Brown, K., Hampson, K and Brandon, P. (eds.) 2005. Clients driving construction innovation, Vols 1 and 2, Brisbane: Cooperative Research Centre for Construction Innovation.

Cassimatis, P. 1969. The Economics of the Construction Industry, National Industrial Conference Board, NY.

Chang, C.Y. and Ive, G. 2007. The hold-up problem in the management of construction projects: A case study of the Channel Tunnel, International Journal of Project Management, 25: 4, 394-404.

Chau, K.W., Raftery, J. and Walker, A. 1998. The baby and the bathwater: research methods in construction management, Construction Management and Economics, 16: 1, 99-104.

de Valence, G. 2010. Innovation, Procurement and construction industry development, Australasian Journal of Construction Economics and Building, 10: 4, 50-59.

de Valence, G. 2001 (reprint 2010). Defining an industry: what is the size and scope of the Australian building and construction industry? The Australasian Journal of Construction Economics and Building, 1: 1, 53-65. 
Eichner, A. 1973. A theory of the determination of the mark-up under oligopoly, Economic Journal, 83 1184-1200.

Eichner, A. 1976. The Megacorp and Oligopoly, New York: Cambridge University Press.

Fairclough, J. 2002. Innovation in the Construction Industry - a Review of Government R\&D Policies and Practices, Department of Trade and Industry, London.

Gruneberg, S. and Ive, G. 2000. The Economics of the Modern Construction Firm, London: Macmillan.

Hall, R.L. and Hitch, C.J. 1939. Price Theory and Business Behaviour, Oxford Economic Papers, 12-45.

Hamouda, O. F. and Harcourt, G.C. 1988. Post-Keynesianism: From Criticism to Coherence?, Bulletin of Economic Research, 40: 1,1-33.

Harcourt, G.C. 2006. The Structure of Post-Keynesian Economics: The Core Contributions of the Pioneers. Cambridge: Cambridge University Press.

Harriss, C. 1998. Why research without theory is not research: A reply to Seymour, Crook and Rooke, Construction Management and Economics, 16: 1, 113-116

Hillebrandt, P. 1974. Economic Theory and the Construction Industry, London: Macmillan.

Hillebrandt, P. and Cannon, J. 1990. The Modern Construction firm, London: Macmillan. 
Ive, G. 1990. Structures and strategies: An approach towards international comparison of industrial structures and corporate strategies in the construction industries of advanced capitalist societies, Habitat International, 14: 2/3, 45-58.

Ive, G. 1994. A theory of ownership types applied to the construction majors, Construction Management and Economics, 12: 4, 349-364.

Ive, G. and Chang, C.Y. 2007. The principle of inconsistent trinity in the selection of procurement systems, Construction Management and Economics, 25: 7, 677-690.

Ive, G. and Groak, S. 1986. Economics and technological change: Some implications for the study of the building industry, Habitat International, 10: 4, 115-132.

Ive, G. and Gruneberg, S. 2000. The Economics of the Modern Construction Sector, London: Macmillan.

Kalecki, M. 1954. Theory of Economic Dynamics, London: Allen and Unwin.

Lawson, T. 1997. Economics and Reality, Oxford: Routledge.

Lawson, T. 2003. Reorienting Economics, London: Routledge.

Lakatos, I. 1977. Proofs and Refutations, Cambridge: Cambridge University Press.

Lowe, J.G. 1990. The fixed capital stock in use by the UK construction industry, Construction Management and Economics, 8, 63-75. 
Means, G.C. 1972. The administered price thesis reconfirmed, American Economic Review, 62, 292306.

Pryke, S. 2004. Twenty-first Century Procurement Strategies: Analysing networks of relationships, RICS Research Papers Series, Vol. 4. No. 27.

Reichstein, T., Salter, A.J. and Gann, D. 2005. Last among equals: a comparison of innovation in construction, services and manufacturing in the UK, Construction Management and Economics, 23: 4, 631-644.

Robinson, J. 1979. Collected Economic Papers Vol. V, Oxford: Basil Blackwell.

Runeson, G. 2000. Building Economics, Geelong: Deakin University Press.

Runeson, G. 1997. The role of theory in construction management research: comment, Construction Management and Economics, 15: 3, 299-302.

Runeson, G. and de Valence, G. 2008. 'The New Construction Industry' in Ruddock, L. (ed.) Economics for the Modern Built Environment, Taylor \& Francis, London, 199-211

Seymour, D. and Rooke, J. 1995. The culture of the industry and the culture of research, Construction Management and Economics, 13: 6, 511-523.

Seymour, D., Crook, D. and Rooke, J. 1997. The role of theory in construction management: a call for debate, Construction Management and Economics, 15: 1, 117-119. 
Seymour, D., Crook, D. and Rooke, J. 1998. The role of theory in construction management: reply to Runeson, Construction Management and Economics, 16: 1, 109-112.

Smyth, H. 2010. Construction industry performance improvement programmes: the UK case of demonstration projects in the 'Continuous Improvement' programme, Construction Management and Economics, 28: 3, $255-270$.

Smyth, H. and Pryke, S. (eds.) 2008. Collaborative Relationships in Construction: Developing frameworks and networks. Oxford, Wiley-Blackwell.

Slaughter, S. 1998. Models of construction innovation. Journal of Construction Engineering and Management, 124 (30), 226-31. 